\begin{tabular}{|l|l|}
\hline Postprint Version & 1.0 \\
\hline Journal website & http://dx.doi.org \\
\hline Pubmed link & \\
\hline DOI & $10.1080 / 13548500220139421$ \\
\hline
\end{tabular}

\title{
Health promoting effects of the physician-patient encounter
}

\section{A. M. VAN DULMEN \& J. M. BENSING}

Nivel (Netherlands Institute of Health Services Research), Utrecht, the Netherlands

\begin{abstract}
The efficacy of a medical treatment partly depends on the interpersonal context in which an intervention takes place. By identifying what factors in the medical encounter engender effect beyond that of the therapeutic intervention, treatment outcome is likely to increase. This study gives an overview of the most important literature examining the relationship between physiological outcome measures and factors pertaining to the medical health care visit. Research findings suggest that the stressfulness of the medical encounter impacts on a patient's health negatively. Yet, this negative experience can be transformed into a positive one when physicians use empathic and patient-centred communication styles and assist patients in altering incorrect ideas about their complaints.
\end{abstract}

\section{INTRODUCTION}

Nowadays, people have plenty of access to various sources of medical information through, for instance, television programmes or the Internet (e.g. Kim et al., 2001; Toub \& Dunkel, 2001). At the same time, there is a growing interest in the inherent potential of a face-to-face encounter with a physician (Di Blasi et al., 2001; Moerman \& Jonas, 2000). Medical visits seem to have health promoting effects beyond that of the physical or pharmacological intervention. This could explain why there is no one-to-one relationship between a medical intervention and its therapeutic effects (Turner et al., 1994). The efficacy of a medical treatment seems to depend also on the interpersonal context in which the intervention takes place. Presumably, certain aspects of the meeting with the physician influence a patient's health in a more or less direct way. If this is true, many therapeutic effects will not take place without an actual visit to a physician. Attention for this so called 'black box of the physician's healing power' (White, 1988) is warranted because there are indications that the quality of the physician-patient relationship is declining (Murphy et al., 2001) and, at least in the USA, the number of malpractice suits caused by patients' negative perceptions of this relationship is increasing (Moore et al., 2000).

The quality of the medical encounter is usually assessed in terms of patient satisfaction or quality of life (Jackson et al., 2001; Ong et al., 2000; Roter et al., 1999; inter alia). Studies indicate that an empathic, patient-centred consulting style and ample opportunity for the patient to participate in the conversation enhances visit outcome (Stewart et al., 2000; Sullivan et al., 2000). Yet, outcome measures like satisfaction do not provide insight into the influence of a medical encounter on patients' physical health. In this respect, more objective, physiological outcome measures (e.g. blood pressure, blood glucose, heart rate, cortisol, immune function) may be more appropriate. The positive and negative effects of the medical encounter may be expected to have a bearing on a broad range of 
factors, such as on the extent in which a physician employs empathic behaviour or on the amount of biomedical information exchanged between both parties. In other words, both affective and instrumental communication may influence the outcome of the medical visit (Bensing, 2000). As a result of the growing insight into the interaction between the brain, the immune system and the endocrine system, attention on the effects of health care visits is increasing as well. In view of this renewed attention, it was considered worthwhile to explore the state of the art in this field. The aims of such an exploration were to offer handles to improve patients' health in case of somatically unexplained physical symptoms, to increase the effect of available therapeutic interventions and to reinforce the value of a medical visit. The present paper therefore focused on the identification of health promoting constituents which are amenable to change and applicable within the medical encounter, thereby excluding fixed factors such as patient or illness characteristics. By providing a broad overview of the most relevant literature in this area, the following question was addressed: Is there a relationship between physiological outcome measures and factors pertaining to the medical health care visit? A medical visit may produce physiological responses in different ways: (1) by virtue of the fact that it is an interpersonal encounter, in which persons employ verbal activity and their conversation centres around a certain topic; (2) by the extent in which the physician uses affective communication, i.e. communication aimed at putting a patient at ease and releasing their emotions; and (3) by physicians' instrumental communication, i.e. communication aimed at providing information and influencing a patient's cognitions.

\section{AN INTERPERSONAL ENCOUNTER}

A medical visit is a special form of an interpersonal meeting. Several features of this meeting appear to influence patient health either positively or negatively.

\section{Status difference}

Any meeting between two persons produces physiological reactions because, as Cacioppo et al. (1990) demonstrated, the mere idea that one is being observed can elicit subtle physiological reactions. This reaction is expected to be even stronger in medical encounters which are, by definition, characterized by a meeting between two persons with a different social status. A provider's status contributes to the effects of a medical treatment. Blood pressure measured by nurses appears, in general, to be lower than that measured by physicians (Veerman \& van Montfrans, 1993). This phenomenon has been known as the 'white coat' effect and is often explained by the feelings of heightened stress and uncertainty surrounding a visit to the physician.

\section{Verbal activity}

Apart from the influence of meeting a higher status person, the effect of talking has been investigated as well. Several studies have indicated that talking provokes cardiovascular reactions (Liehr, 1992; le Pailleur \& Landais, 1994; le Pailleur et al., 1996; Stein \& Boutcher, 1993). These findings suggest that the verbal activity of talking is, in itself, a sufficient explanation of the white coat phenomenon described above. It appears that the higher the resting value of blood pressure, the greater the rise in blood pressure. So the increase in blood pressure in hypertensive individuals when they are talking is greater than that in normotensive individuals (Lynch et al., 1981). The extent of the reaction appears to be comparable with that of a regular exercise stress test (Thomas et al., 1992), does not change as a result of the use of antihypertensives (Dimsdale et al., 1992) and occurs both in an experimental and a medical setting (Lynch et al., 1982). The increase in blood pressure may be a result of the experienced uncontrollability and dependent position in which a patient finds him or herself during a visit to the physician. Although verbalization seems to produce significant physiological changes, the blood pressure of deaf people also rises while signing (Malinow et al., 1986). The rise in blood pressure can therefore not simply be connected with the motor activity while talking, but may also be the result of the stressful communicative procedure itself. So, regardless of the influence of a therapeutic intervention, physiological changes appear to be inherently associated with a visit to a physician.

\section{Topic of discussion}

The motor activity involved in talking is not the only factor that is responsible for the increase in blood pressure. In view of the positive relationship that has been identified between the level of blood pressure and discussion of stressful events (Fontana \& McLaughlin, 1998; Liehr et al., 1997; le 
Pailleur et al., 1996), the content of the words that are spoken (emotional versus neutral) appears to have a greater effect on blood pressure. Individuals seem to respond to a stressful situation like a medical visit with an increase in blood pressure due to conditioning (Nyklícek et al., 1998). The assessment of the situation, and possibly also other cognitions, plays an as yet unexplained mediating role. Both the presence and the status of a physician, the verbal activity and the content of the conversation would thus appear to have a bearing on physiological parameters.

\section{Emotional disclosure}

In view of the association between talking about stressful events and increases in blood pressure, it is likely that talking with a physician about symptoms and their perception will also impact on a person's state of health. It is, after all, a known fact that the suppression of thoughts, feelings and behaviour demands physiological efforts. In the short term, that suppression can result in an increase in autonomous activity, and in time it can even come to act as a cumulative stressor, thus increasing the risk of physical complaints (Pennebaker, 1999; Pennebaker \& Susman, 1988). Research shows that the verbalization of stressful experiences leads to a rise in blood pressure, but in the long term - probably as a result of increased insight and cognitive changes-results in a better state of health in the form of better immune function, lower HbA1 and blood pressure (Esterling et al., 1990; 1994; Kaplan et al., 1989; Orth et al., 1987; Pennebaker, 1989; Pennebaker \& Susman, 1988).

It appears from studies in rheumatic patients that both everyday vicissitudes, such as a quarrel or a car accident, and traumatic experiences, such as a divorce or someone's death, are related to an objectively measurable resurgence of the complaints (Thomason et al., 1992; Zautra et al., 1989). Talking about the emotions that have been experienced appears to have important health-promoting effects for these particular patients (Kelley et al., 1997).

\section{AFFECTIVE COMMUNICATION}

A person does not tell his or her personal story just like that. To do so they need to feel that they are in a trusted environment and be encouraged to do so (Suchman et al., 1997). A good physician-patient relationship is essential in this respect. Such a relationship can be promoted by first putting a patient at their ease. One of the ways of doing this might be by making social conversation or by making a little joke.

\section{Social conversation}

There is evidence to suggest that social conversation contributes to patient satisfaction. It appears to give patients the feeling that they represent more than just their illness (Hall et al., 1998). This greater satisfaction promotes compliance and thus, indirectly, patient health. The extent to which social conversation in itself also has a direct bearing on someone's state of health has not been investigated. Research has, however, been conducted into the effect of humour on the short-term stress of a medical consultation. From this it appears that humour has a buffering effect on stress (Gaberson, 1991). This relaxing effect can be expected to contribute to the patient's wellbeing.

\section{Emotional support and empathy}

A further important prerequisite when trying to induce a patient to talk is by offering emotional support. In general, the perception of ongoing support protects an individual against the pathological influence of stressful events (Cohen \& Wills, 1985).This is because the presence of someone who has the intention of providing help appears to bring about a reduction in anxiety and depression (Foa et al., 1991). The knowledge that there is a physician with whom one can discuss one's problems can therefore also have a beneficial effect. It can be assumed, however, that long-term improvement in a patient's state of health demands more than simply 'being there' for them. It appears that an empathic interaction, in the form of reassuring words or affective contact, can lead to a reduction in pain and blood pressure (Hwang et al., 1998; Weiss, 1990). It would thus appear to be worthwhile not only from an ethical viewpoint but also in the interests of health promotion to ensure that a patient feels at ease during the stress-inducing medical consultation. In a recent literature review, empathy even turned out to be the interaction parameter with the strongest positive healthpromoting effects (Di Blasi et al., 2001). 


\section{Patient-centredness}

Another way for a physician to keep pace with the patient is by patient-centred interviewing. Patientcentred care is care in which the doctor responds to the patient in such a way as to allow the patient to express all of his or her reasons for coming, including symptoms, thoughts, feelings and expectations (Henbest \& Stewart, 1990). Certainly, when patients are confronted with a disorder with an uncertain course, the outcome of which is to a great extent determined by the behaviour of the patients themselves (e.g. hypertension, diabetes or coronary heart disease), it is extremely important to explore and discuss the views and motivation of the patient, especially since physicians and patients frequently differ in the value that they attach to personally-relevant information (Chaitchik et al., 1992).

Furthermore, the patient's views can assist the physician in making a diagnosis (Peppiatt, 1992).

Research shows that the extent of a physician's patient-centredness contributes to the improvement of somatic complaints in patients with headaches, rheumatism, gastric ulcer, diabetes and breast cancer (Bertakis et al., 1998; Greenfield et al., 1985; the Headache study, 1986; Henbest \& Fehrsen, 1992; Henbest \& Stewart, 1990; Kaplan et al., 1989; Lorig et al., 1993; Rost et al., 1991).

\section{Expectations and role preferences}

An effective use of a patient-centred consulting style is likely to result in a discussion of needs and expectations. This is important because patients' as well as physicians' expectations appear to impact upon the outcome of a medical visit. Patients' expectations can be either related to the health care process (process expectations), the outcome (outcome expectations) or the way in which a patient considers him or herself able to cope with their symptoms effectively (self-efficacy expectations) (Crow et al., 1999). Positive expectations seem to increase patients' health in terms of lowered blood pressure (Stuart et al., 1987), immunological changes (Antoni et al., 1991) and reduced pain (Lorig et al., 1993). Physicians' expectations can impact on a patient's health as well. A study by Galer et al. (1997) shows that the more physicians expect a patient's pain to be relieved, the more this pain does, in fact, diminish. This suggests that physicians in a subtle way transmit their expectations to the patients. The expectations of the physician may even be more determinative for health effects in the patient than the expectations of the patient him or herself (Wirth, 1995). Maybe this has to do with the fact that, contrary to physicians, patients seem to have rather fixed role expectations (Ewart \& Till, 1998) and may therefore be less capable of adapting themselves to changing circumstances.

\section{INSTRUMENTAL COMMUNICATION}

Apart from communicating affect, physicians also provide information. This paragraph explores how this supply of information influences physiological outcome.

\section{Informational need}

For the patient, the need for information is an important reason for consulting a physician (van der Kar et al., 1992). The fulfilment of this need will therefore also, in itself, have beneficial effects.

Diagnostic and prognostic information seem to be associated with greater improvement in symptoms and functional health status two weeks after a health care visit (Jackson \& Kroenke, 2001; Sox et al., 1981). Good information also has a bearing on how quickly a patient recovers after an operation (Cupples, 1991). Giving patients a recording of a discussion with the physician helps them to retain information and also helps to reduce the number of visits to the physician (Hogbin et al., 1992; McHugh et al., 1995; Rylance, 1992). The stress that is associated with a visit to a physician can even lead to patients having difficulty remembering information and thus failing to adhere to a physician's advice. A high level of the stress hormone cortisol can damage the hippocampus (Bremner, 1999), an intermediate stage in the long-term storage of declarative knowledge, or else temporarily block it off (Newcomer et al., 1999), with the result that either no information at all is stored, or else only fragmented information.

A face-to-face encounter between a physician and a patient increases the effectiveness of behavioural change interventions (Kreuter et al., 2000), because the information provided by a physician influences a patient's expectations and, subsequently, the way he or she perceives their symptoms. Even the mere fact of naming the symptoms or establishing a medical diagnosis has a therapeutic effect, since it gives a meaning to the complaints and can provide a feeling of reassurance (Brody \& Waters, 1980). A prerequisite is, however, that the diagnosis fits in with the patient's frame of 
reference (Bügel \& van Everdingen, 1998). Patients generally benefit from precise information on the duration and course of their complaints (Thomas, 1987). Information exerts influence by arousing positive expectations (Crow et al., 1999), by lowering anxiety (Leckie, 1994), by mobilizing support and by creating a feeling of control (Ong et al., 1995). The manner in which information is provided appears to be crucial. In particular, honest, open and personally-tailored communication puts patients at their ease (Sardell \& Trierweiler, 1993). Information can also have an adverse impact on health, e.g. by increasing blood pressure (Amigo et al., 1993; Orth et al., 1987).

\section{Volume of information}

Information may generate adverse effects because patients differ in the volume of information they require. Physicians' provision of information depends in part on the need for information and the concerns of the patient in question (Street, 1991). It is worthwhile in this connection to divide patients into two categories: patients who want as much information as possible about what is wrong with them (the so-called 'monitors') and patients who want to know as little as possible ('blunters') (Miller \& Mangan, 1983; Miller et al., 1988). If the volume of information does not conform to one of these coping styles, there appear to be adverse psychophysiological consequences. Personally-tailored information can only be given by adopting a patient-centred approach, whereby the physician is mindful of the patients' individual needs. In that way, patients can themselves exercise control over the nature and amount of information they receive through their individual communication style. This appears to have beneficial effects on health, e.g. via a reduction in HbA1 (Greenfield et al., 1988). It should be noted that one coping style is not, by definition, any more effective than the other. In fact, this appears to depend on the controllability of the disorder, the nature of the outcome measures (proximal or distal) and the stage which the disease has reached (Kiyak et al., 1988).

\section{Influencing cognitions and behaviour}

Information given by a physician is cognitively and emotionally processed by the patient. This processing has an influence on the physiological activity and on the immune system (Brosschot et al., 1991; Lutgendorf et al., 1994) and, as such, influences physical complaints. Negative cognitions (e.g. catastrophizing) and somatic attributions appear to be capable of increasing the intensity of pain (van Dulmen et al., 1997; Shutty et al., 1990; Summers et al., 1991; Turk \& Rudy, 1992) and perpetuating symptoms of chronic fatigue (Vercoulen et al., 1996). Changing such cognitions will therefore impact positively on physical complaints and even on more serious disorders such as AIDS and cancer (Kiecolt-Glaser \& Glaser, 1992). Emotional expression alone is, in point of fact, insufficient to influence unfavourable cognitions (Murray et al., 1989; Schilte et al., 2001). Active intervention on the part of the care provider is needed if disclosure is to have a long-term effect. For example, the provision of clear information and advice to hypertensive patients appears to be capable of reducing misconceptions about a disorder, resulting in better control over blood pressure (Inui et al., 1976). Using and discussing a symptom diary serves the same purpose (Blankenstein, 2001). Overall, attention to psychosocial factors appears to enhance health (Padgett et al., 1988).

Various controlled (Bradley et al., 1987; Devine \& Spanos, 1990; inter alia) and uncontrolled studies (Blankenstein, 2001; van Dulmen et al., 1996; Williams et al., 1993; inter alia) have been carried out into the effects of interventions aimed at modifying cognitions and emotions in the treatment of physical complaints in medical practice. Alongside conventional drug treatment, simple cognitive behaviour-therapy strategies_-for example encouraging patients to perform relaxation exercises combined with the restructuring of dysfunctional ideas - can provide long-term relief of headache complaints (Vasterling et al., 1993). Advice from the physician, such as 'take it easy' and 'find something to take your mind off it' may possibly have the same effect. Physicians perform cognitive interventions by explaining to the patient the connection between the meaning and the perception of their complaints, encouraging physical and psychological relaxation, identifying negative ideas and replacing them with patient-specific positive ideas. After a visit to their physician, patients frequently modify their ideas about the cause of their complaints and often already feel less concerned once they have heard that they have not contracted a life-threatening disease (van Dulmen et al., 1995). This reassurance can manifest itself in a reduction both in physical complaints and in the accompanying use of health services (visits to the physician and use of medication). 


\section{CONCLUSION}

The present study provided an overview of the most important studies which at present support the concept of a relationship between what goes on in a medical visit and the physiological outcome that results from it. Owing to the topic of discussion and the motor act of verbalization, a medical visit seems to be stressful in itself. By effectively using their affective and instrumental communicative behaviour, a physician may be able to neutralize this negative experience or even to transform it into something positive.

A number of factors within the medical encounter appeared to enhance this positive influence on patients' health. Some of these aspects, such as an empathic and patient-centred communication style, were already known for their positive effects on subjective outcome measures (Stewart et al., 2000; Sullivan et al., 2000). The physiological parameters that were used in examining more objective health outcomes mainly concerned cardiovascular and immunological outcome. These proximal measures give an impression of short-term physiological reactivity but may not suffice as indicators of patients' health. Distal measures such as patient recovery and long-term health would be more suitable for this purpose. Apart from relying solely on (short-term) biological outcome parameters, asking patients themselves if they feel better is also recommended (Wright, 2000). After all, outcomes that matter to patients are probably as much related to mental and social health as to physical health (Sherbourne et al., 1999). Therefore, empirical studies with different outcome measures, e.g. general susceptibility for diseases, the length of recovery after an invasive intervention or the extent to which the patient feels better, continue to be needed to further prove the effects of the context in which the medical intervention takes place.

Apparently, disclosure of emotional experiences can, in itself, have positive effects on health. It is therefore possible that talking about the stressfulness of the situation or of the perception of a disorder plays a major role in the therapeutic effects achieved in somatic health care. On the basis of the studies described in this paper, more effects on health are likely to be achieved if a health care provider also assists a patient in changing their perception of the events (Murray et al., 1989). The health effects arising from the airing of emotional stress could be directly related to the positive correlation that exists between psychological stress and somatic symptoms (Simon et al., 1996). Yet, even in patients receiving palliative chemotherapy, emotional burden is frequently ignored (Detmar et al., 2001). A primary requirement is that physicians must give patients enough opportunity to disclose their concerns and worries. Recent research shows that physicians actually do this in only $28 \%$ of cases. It is worth noting that when physicians do allow their patients to say what is on their minds, the consultation in question appears only to last an average of six seconds longer (Marvel et al., 1999). In addition, Levinson et al. (2000) found that physicians frequently miss opportunities to adequately acknowledge patients' feelings and that visits with missed opportunities even tend to be longer.

Although a face-to-face encounter does not seem to be necessary for providing information to a patient, patients do prefer to receive information from their physician compared to written or electronic information (Terry \& Healey, 2000). Besides, telemedicine does not seem to have any clinical benefits (Currell et al., 2000). The present study suggested that the medical visit has added value which contributes to patients' wellbeing and health. From this it follows that evidence-based efforts directed at improving physician-patient communication are a key element in improving care (Kenny, 1999). A physician can make use of these health-promoting effects by realizing that a medical visit is frequently experienced as a stressful event, by giving patients the opportunity to express their concerns and worries and by providing the volume of information patients need.

\section{REFERENCES}

Amigo, l., Cuesta, V., Ferna'ndez, A. \& Gonza' lez, A. (1993). The effect of verbal instructions on bloodpressure measurement. Journal of Hypertension, 11, 293-296.

Antoni, M.H., Baggett, L., Ironson, G., LaPerriere, A., August, S., Klimas, N., Schneiderman, N. \& FLETCHER, M.A. (1991). Cognitive-behavioral stress management intervention buffers distress responses and immunological changes following notification of HIV-1 seropositivity. Journal of Consulting and Clinical Psychology, 59, 906-915.

BENSING, J.M. (2000). Bridging the gap. The separate worlds of evidence-based medicine and patient-centered medicine. Patient Education and Counseling, 39, 17-25. 
Bertakis, K.D., Callahan, E.J., Helms, L.J., Azari, R., Robbins, J.A. \& Miller, J. (1998). Physician practice styles and patient outcomes. Differences between family practice and general internal medicine. Medical Care, 36, 879-891.

BLANKENSTEIN, N. (2001). Somatising patients in general practice. Reattribution, a promising approach. Amsterdam: VU (thesis).

Bradley, L.A., Young, L.D., Anderson, K.O., Turner, R.A., Agudelo, C.A.,McDaniel, L.K., Pisko, E.J., SEmble, E.L. \& Morgan, T.M. (1987). Effects of psychological therapy on pain behavior of rheumatoid arthritis patients. Arthritis and Rheumatism, 30, 1105-1114.

BREMNER, J.D. (1999). Does stress damage the brain? Biological Psychiatry, 45, 797-805.

BRody, H. \& WATERS, D.B. (1980). Diagnosis is treatment. Journal of Family Practice, 10 , 445-449.

Brosschot, J.F., Smelt, D., de Smet, M., Heijnen, C.J., OlfF, M., Ballieux, R.E. \& Godaert, G.L.R. (1991). Effects of experimental psychological stress on T-lymphocytes and NK cells in man: an exploratory study. JouRNAL OF PSYCHOPHYSIOLOGY, 5, 59-67.

BügeL, P.C. \& van EVERDINGEN, J.J.E. (1998). De placebo werking van taal. Tijdschrift voor Gezondheidswetenschappen, 7, 403-406.

Cacioppo, J.T., Rourke, P.A., Marshall-Goodell, B.S., Tassinary, L.G. \& Baron, R.S. (1990). Rudimentary physiological effects of mere observation. Psychophysiology, 27, 177-186.

Chaitchik, S., Kreitler, S., Shaked, S., Schwartz, I. \& Rosin, R. (1992). Doctor-patient communication in a cancer ward. Journal of Cancer Education, 7, 41-54.

COHEN, S. \& WiLLS, T.A. (1985). Stress, social support, and the buffering hypothesis. Psychological Bulletin, 98, 310-357.

Crow, R., Gage, H., Hampson, S., Hart, J., Kimber, A. \& Thomas, H. (1999). The role of expectancies in the placebo effect and their use in the delivery of health care: a systematic review. Health Technology Assessment, 3 CuPPLES, S.A. (1991). Effects of timing and reinforcement of preoperative education and recovery of patients having coronary artery bypass graft surgery. Heart Lung, 29, 654-660.

Currell, R., Urquhart, C., WainWright, P. \& LeWIS, R. (2000). Telemedicine versus face to face patient care: effects on professional practice and health care outcomes. Cochrane Database Systematic Review, 2, CD002098.

Detmar, S.B., Muller, M.J., Wever, L.D. \& Schornagel, J.H., Aaronson, N.K. (2001). The patient-physician relationship. Patient-physician communication during outpatient palliative treatment visits: an observational study. Journal of the American Medical Association, 285, 1351-1357.

DEVINE, D.P. \& SpANos, N.P. (1990). Effectiveness of maximally different cognitive strategies and expectancy in attenuation of reported pain. Journal of Personality and Social Psychology, 58, 672-678.

Di Blasi, Z., Harkness, E., Ernst, E., Georgiou, A. \& Kleijnen, J. (2001). Influence of context effects on health outcomes: a systematic review. The Lancet, 357, 757-762.

Dimsdale, J.E.,Mills, P., Ziegler, M., Leitz, K. \& Nelesen, R. (1992). Converting enzyme inhibition and blood pressure reactivity to psychological stressors. Hypertension, 20, 210-213.

van Dulmen, A.M., Fennis, J.F.M., Mokkink, H.G.A., van der Velden, H.G.M. \& BleiJenberg, G. (1995). Doctor-dependent changes in complaint-related cognitions and anxiety during medical consultations in functional abdominal complaints. Psychological Medicine, 25, 1011-1018.

van Dulmen, A.M., Fennis, J.F.M., Mokkink, H.G.A. \& BleiJenberg, G. (1996). The relationship between complaint- related cognitions in referred patients with irritable bowel syndrome and subsequent health care seeking behaviour in primary care. Family Practice, 13, 1217.

van Dulmen, A.M., Fennis, J.F.M., Mokkink, H.G.A., van der Velden, H.G.M. \& BleiJenberg, G. (1997). Persisting improvement in complaint-related cognitions initiated during medical consultations in functional abdominal complaints. Psychological Medicine, 27, 725-729. 
Esterling, B.A., Antoni, M.H., Kumar, M. \& Schneiderman, N. (1990). Emotional repression, stress disclosure responses, and Epstein-Barr viral capsid antigen titers. Psychosomatic Medicine, 52, 397-410.

Esterling, B.A., Antoni, M.H., Fletcher, M.A.,Margulies, S. \& Schneiderman, N. (1994). Emotional disclosure through writing or speaking modulates latent Epstein-Barr virus antibody titers. Journal of Consulting and Clinical Psychology, 62, 130-140.

EWART, B.W. \& TILL, C.A. (1998). Monologue or dialogue: role preferences of patients and GPs within the consultation. Psychology, Health and Medicine, 3, 395-404.

Foa, E.B., Rothbaum, B.O., Riggs, D.S. \& Murdock, T.B. (1991). Treatment of posttraumatic stress disorder in rape victims: a comparison between cognitive-behavioral procedures and counseling. Journal of Consulting and Clinical Psychology, 59, 715-723.

FONTANA,A.\&MCLAUGHLIN, M. (1998). Coping and appraisal of daily stressors predict heart rate and blood pressure levels in young women. Behavioral Medicine, 24, 5-16.

GABERSON, K.B. (1991). The effect of humorous distraction on preoperative anxiety. AORN Journal, 54, 1258-1264.

Galer, B.S., Schwartz, L. \& Turner, J.A. (1997). Do patient and physician expectations predict response to pain-relieving procedures? Clinical Journal of Pain, 13, 348-351.

GREENFIELD, S., KAPLAN, S.H. \& WARE, J.E. (1985). Expanding patient involvement in care. Annals of Internal Medicine, 102, 520-528.

Greenfield, S., Kaplan, S.H., Ware, J.E., Yano, E.M. \& Frank, H.J.L. (1988). Patients' participation in medical care. Journal of General Internal Medicine, 3, 448-457.

Hall, J.A., Milburn, M.A., Roter, D.L. \& Daltroy, L.H. (1998). Why are sicker patients less satisfied with their medical care? Tests of two explanatory models. Health Psychology, 17, 70-75.

Headache Study Group of the University of Western Ontario (1986). Predictors of outcome in headache patients presenting to family physicians-a one year prospective study. Headache, 26, 285-294.

Henbest, R.J. \& Stewart,M.A. (1990). Patient-centredness in the consultation. 2. Does it really make a difference? Family Practice, 7, 28-33.

HENBEST, R.J. \& FEHRSEN, G.S. (1992). Patient-centredness: is it applicable outside the west? Its measurement and effect on outcomes. Family Practice, 9, 311-317.

Hogbin, B., JeNKINS, V.A. \& PARKIN, A.J. (1992). Remembering 'bad news' consultations: an evaluation of tape-recorded consultations. Psycho-oncology, 1, 147-154.

Hwang, S.L., Chang, Y., Ko, W.J. \& LeE,M.B. (1998). Stress-reducing effect of physicians's tape-recorded support on cardiac surgical patients in the intensive care unit. Journal of Formos Medical Association, 97, 191-196.

INUI, T.S., YouRTEE, E.L. \&WiLliamson, J.W. (1976). Improved outcomes in hypertension after physician tutorials: a controlled trial. Annals of Internal Medicine, 84, 646-651.

Jackson, J.L., Chamberlin, J. \& Kroenke, K. (2001). Predictors of patient satisfaction. Social Science and Medicine, 52, 609-620.

JACKSON, J.L. \& KROENKE, K. (2001). The effect of unmet expectations among adults presenting with physical symptoms. Annals of Internal Medicine, 134, 889-897.

Kaplan, S.H., GREenFIELD, S. \& WARE, J.E. (1989). Assessing the effects of physician-patient interactions on the outcomes of chronic disease. Medical Care, 27, S110-S127.

van der Kar, A.,Knottnerus, A.,Meertens, R.,Dubois, V. \&Kok, G. (1992). Why do patients consult the general practitioner? Determinants of their decision. British Journal of General Practice, 42, 313-316.

Kelley, J.E., LumLey, M.A. \& Leisen, J.C.C. (1997). Health effects of emotional disclosure in rheumatoid arthritis patients. Health Psychology, 16, 331-340.

KENNY, N.P. (1999). Speaking of values: the ethics of communication. Cancer Prevention and Control, 3, 31-35.

Kiecolt-Glaser, J.K. \& Glaser, R. (1992). Psychoneuroimmunology: can psychological interventions modulate immunity? Journal of Consulting and Clinical Psychology, 60, 569-575. 
Kıм, H.S., Kıм, E. \& Kıм, J.W. (2001). Development of a breast self-examination program for the Internet: health information for Korean women. Cancer Nursing, 24,156-161.

KiYak, H.A., Vitaliano, P.P. \& Crinean, J. (1988). Patients' expectations as predictors of orthognathic surgery outcomes. Health Psychology, 7, 251-268.

Kreuter, M.W., ChHedA, S.G. \& Bull, F.C. (2000). How does physician advice influence patient behavior? Evidence for a priming effect . Archives of Family Medicine, 9, 426433.

LECKIE, J. (1994). The effects of informational intervention on state anxiety and satisfaction in patients undergoing bone scan. Nuclear Medical Community, 15, 921-927.

LeVinson, W., GoraWARA-Bhat, R. \& Lamb, J. (2000). A study of patient clues and physicians' responses in primary care and surgical settings. Journal of the American Medical Association, 284,1021-1027.LIEHR, P. (1992). Uncovering a hidden language: the effects of listening and talking on bloodpressure and heart rate. Archives of Psychology Nursing, 6, 306-311.

Liehr, P., Meininger, J.C.,Mueller, W., Chandler, S.P. \& Chan, W. (1997). Blood pressure reactivity in urban youth during angry and normal talking. Journal Cardiovascular Nursing, 11, 85-94.

LoRIG, K.R.,MAZONSON, P.D. \& Holman, H.R. (1993). Evidence suggesting that health education for self-management in patients with chronic arthritis has sustained health benefits while reducing health care costs. Arthritis and Rheumatism, 36, 439-446.

LUtGendoRF, S.K., ANTONI,M.H.,KumAR,M. \& SCHneIDERMAN, N. (1994). Changes in cognitive coping strategies predict EBV-antibody titre change following a stressor disclosure induction. Journal of Psychosomatic Research, 38, 63-78.

LyNCH, J.J., Long, J.M., Thomas, S.A.,Malinow, K.L. \& Katcher, A.H. (1981). The effects of talking on the blood pressure of hypertensive and normotensive individuals. Psychosomatic Medicine, 43, 25-33.

Lynch, J.J., Thomas, S.A., Long, J.M., Malinow, K.L., Friedmann, E. \& Katcher, A.H. (1982). Blood pressure changes while talking. Israel Journal of Medical Science, 18, 575-579 Malinow, K., Lynch, J.J., Foreman, P.J., Friedman, E. \& Thomas, S.A. (1986). Blood pressure increases while signing in a deaf population. Psychosomatic Medicine, 48, 95101 Marvel, M.K., Epstein, R.M., Flowers, K., Beckman, H.B. (1999). Soliciting the patient's agenda: have we improved? Journal of the Americal Medical Association, 281, 283-287.

Mchugh, P., Lewis, S., Ford, S.,Newlands, E., Rustin, G., Coombes,C.,Smith, D., O'Reilly, S.\&FALLOWFIELD, L. (1995). The efficacy of audiotapes in promoting psychological wellbeing in cancer patients: a randomised, controlled trial. British Journal of Cancer, 71 , 388-392.

Miller, S.M.\&MANGan, C.E. (1983). Interacting effects of information and coping style in adapting to gynecologic stress: should the doctor tell all? Journal of Personality and Social Psychology, 45, 223-236.

Miller, S.M., Brody, D.S. \& Summerton, J. (1988). Styles of coping with threat: implications for health. Journal of Personality and Social Psychology, 54, 142-148.

MoERmAN, D.E. \& JonAs, W.B. (2000). Toward a research agenda on placebo. Advances in Mind-Body Medicine, 16, 33-46.

Moore, P.J., Adler, N.E. \& Robertson, P.A. (2000). Medical malpractice: the effect of doctor-patient relations on medical patient perceptions and malpractice intentions. Western Journal of Medicine, 173, 244-250.

Murphy, J.,Chang,H.,Montgomery, J.E., Rogers,W.H.\& SAfran, D.G. (2001). The quality of physician-patient relationships. Patients' experiences, 1996-1999. Journal of Family Practice, 50, 123-129.

MurRay, E.J., LAMnin, A.D. \& CARVER, C.S. (1989). Emotional expression in written essays and psychotherapy. Journal of Social and Clinical Psychology, 8, 414-429.

Newcomer, J.W., Selke, G., Melson, A.K., Hershey, T., Craft, S., Richards, K. \& Alderson, A.L. (1999). 
Decreased memory performance in healthy humans induced by stress-level cortisol treatment. Archives of General Psychiatry, 56, 527-533.

NYKLIÍCEK, I., VINGERHOETS, A.J.J.M. \& VAN HECK, G.L. (1998).The under-reporting tendency of hypertensives: an analysis of potential psychological and physiological mechanisms. Psychology and Health, 13, 1-21.

Ong, L.M.L., DeHAes, J.C.J.M., KRUIJVER, I.P.M., DE ReIJKE, TH.M. \&LAMmes, F.B. (1995). Het meegeven van een geluidsopname van het poliklinisch oncologisch consult aan de patiënt; ervaringen van patiënten en artsen. [Providing patients with an audio recording of the outpatient oncological consultation: experiences of patients and physicians]. Nederlands Tijdschrift voor Geneeskunde, 139, 77-80.

Ong, L.M., Visser, M.R., Lammes, F.B., van der Velden, J., Kuenen, B.C. \& de Haes, J.C. (2000). Effect of providing cancer patients with the audiotaped initial consultation on satisfaction, recall, and quality of life: a randomized, double-blind study. Journal of Clinical Oncology,18, 3052-3060.

Orth, J.E., Stiles, W.B., Scherwitz, L., Hennrikus, D. \& Vallbona, C. (1987). Patient exposition and provider explanation in routine interviews and hypertensive patients' blood pressure control. Health Psychology, 6, 29-42.

Padgett, D., Mumford, E., Hynes, M. \& CARTer, R. (1988). Meta-analysis of the effects of educational and psychosocial interventions on management of diabetes mellitus. Journal of Clinical Epidemiology, 41, 1007-1030.

LE PAILLEUR, C. \& LANDAIS, P. (1994). Rôle du dialogue médicin-patient dans l'effet 'blouse blanche' au cours de l'hypertension artérielle. Annales de Cardiologie et d'Angéiologie, 43, 135-138.

le Pailleur, C., Vacheron, A., Landais, P., Mounier-Vé hier, C., Feder, J.M., Montgermont, P., JAIS, J.P. \& METZGER, J.P. (1996). Talking effect and white coat phenomenon in hypertensive patients. Behavioral Medicine, 22, 114-121.

Pennebaker, J.W. \& Susman, J.R. (1988). Disclosure of traumas and psychosomatic processes. Social Science and Medicine, 26, 327-332.

Pennebaker, J.W. (1989). Confession, inhibition, and disease. Advances of Experimental and Social Psychology, 22, 211-244.

Pennebaker, J.W. (1999). The effects of traumatic disclosure on physical and mental health: the values of writing and talking about upsetting events. International Journal of Emergency Mental Health, 1, 9-18.

PePpIATt, R. (1992). Eliciting patients' views of the cause of their problems: a practical strategy for GPs. Family Practice, 9, 295-298.

Rost, K.M., Flavin, K.S., Cole, K. \&McGILL, J.B. (1991). Change in metabolic control and functional status after hospitalization. Diabetes Care,14, 881-889.

Roter, D.L., Geller, G., Bernhardt, B.A., Larson, S.M. \& Doksum, T. (1999). Effects of obstetrician gender on communication and patient satisfaction. Obstetrics and Gynecology, 93, 635-641.

RYLANCE, G. (1992). Should audio recordings of outpatient consultations be presented to patients? Archives of Diseases in Childhood, 67, 622-624.

SARDELL, A.N. \& TRIERWEILER, S.J. (1993). Disclosing the cancer diagnosis. Cancer, 72, 33553365.

Schilte, A.F., Portegius, P.J.M., Blankenstein, A.H., van der Horst, H.E., Latour, M.B.F., van EIJK, J.TH.M. \& KNOTTNERUS, J.A. (2001). Randomised controlled trial of disclosure of emotionally important events in somatisation in primary care. British Medical Journal, 323, 86-89.

Sherbourne, C.D., Sturm, R. \&Wells, K.B. (1999). What outcomes matter to patients? Journal of General Internal Medicine, 14, 357-363.

Shutty,M.S.,DeGood, D.E.\& TutTle, D.H. (1990). Chronic pain patients' beliefs about their pain and treatment outcomes. Archives of Physical Medicine and Rehabilitation, 71, 128132.

Simon, G., Gater, R., Kisely, S. \& Piccinelli, M. (1996). Somatic symptoms of distress: an international primary care study. Psychosomatic Medicine, 58, 481-488. 
Sox, H.C., Margulies, I. \& Hill Sox, C. (1981). Psychologically mediated effects of diagnostic tests. Annals of Internal Medicine, 95, 680-685.

Stein, P.K. \& Boutcher, S.H. (1993). Heart-rate and blood-pressure responses to speech alone compared with cognitive challenges in the stroop task. Perception and Motor Skills, 77, 555-563.

Stewart, M., Brown, J.B., Donner, A., McWhinney, I.R., OAtes, J., Weston, W.W. \& Jordan, J. (2000). The impact of patient-centered care on outcomes. Journal of Family Practice, 49, 796-804.

StREET, R.L. (1991). Information-giving in medical consultations: the influence of patients' communicative styles and personal characteristics. Social Science and Medicine, 32, 541-548.

Stuart, E.M., Caudill, M., Leserman, J., Dorrington, C., Friedman, R. \& Benson, H. (1987). Nonpharmacologic treatment of hypertension: a multiple risk-factor approach. Journal of Cardiovascular Nursing, 1, 1-14.

Suchman, A.L.,Markakis, K., Beckman, H.B. \& Frankel, R. (1997). A model of empathic communication in the medical interview. Journal of the American Medical Association, 277, 678-682.

Sullivan, L.M., Stein, M.D., SAvetsky, J.B. \& SAmet, J.H. (2000). The doctor-patient relationship and HIV-infected patients' satisfaction with primary care physicians. Journal of General Internal Medicine, 15, 462-469.

Summers, J.D., Rapoff, M.A., Varghese, G., Porter, K. \& Palmer, R.A. (1991). Psychosocial factors in chronic spinal cord injury pain. Pain, 47, 183-189.

Terry, P.E. \& Healey, M.L. (2000). The physicians' role in educating patients. A comparison of mailed versus physician-delivered patient education. Journal of Family Practice, 49, 314-318.

Thomas, K.B. (1987). General practice consultations: is there any point in being positive? British Medical Journal, 294, 1200-1202.

Thomas, S.A., Freed, C.D., Friedmann, E., Stein, R., Lynch, J.J. \& Rosch, P.J. (1992). Cardiovascular responses of patients with cardiac disease to talking and exercise stress testing. Heart \& Lung, 21, 64-73.

Thomason, B.T., Brantley, P.J., Jones, G.N., Dyer, H.R. \&Morris, J.L. (1992). The relation between stress and disease activity in rheumatoid arthritis. Journal of Behavioral Medicine, 15, 215-220.

TOUB, D.B. \& DuNKEL, E. (2001). The virtual physician office: patient use of an internet-based women's health forum. Obstetrics and Gynecology, 97, S57.

TURK, D.C. \& RUDY, T.E. (1992). Cognitive factors and persistent pain: a glimpse into Pandora's box. Cognive Therapy and Research, 16, 99-122.

TuRner, J.A.,DeYo, R.A., Loeser, J.D., VonKorfF, M. \&FordyCE, W.E. (1994). The importance of placebo effects in pain treatment and research. Journal of the American Medical Association, 271, 1609-1614.

Vasterling, J., Jenkins, R.A., Tope, D.M. \& Burish, T.G. (1993). Cognitive distraction and relaxation training for the control of side effects due to cancer chemotherapy. Journal of Behavioral Medicine, 16, 65-80.

VEERMAN, D.P. \& VANMONTFRANS, G.A. (1993). Nurse-measured or ambulatory blood pressure in routine hypertension care. Journal of Hypertension, 11, 287-292.

Vercoulen, J.H.M.M., Swanink, C.M.A., Fennis, J.F.M.,Galama, J.M.D., van derMeer, J.W.M. \& BLEIJENBERG, G. (1996). Prognosis in chronic fatigue syndrome: a prospective study on the natural course. Journal of Neurology, Neurosurgery, and Psychiatry, 60, 489-494.

WEISS, S.J. (1990). Effects of differential touch on nervous system arousal of patients recovering from cardiac disease. Heart \& Lung, 19, 474-480.

WHITE, K. (1988). The task of medicine. Menlo Park, Califormia: The Henry J. Kaiser Family Foundation.

Williams, A.C., de C, Nicholas, M.K., Richardson, P.H., Pither, C.E., Justins, D.M., Chamberlain, J.H., Harding, V.R., Ralphs, J.A., Jones, S.C., Dieudonne' , I., Featherstone, J.D., Hodgson, D.R., Ridout, K.L. \& Shannon, E.M. (1993). Evaluation of a 
cognitive behavioural programme for rehabilitating patients with chronic pain. British Journal of General Practice, 43, 513-518.

WIRTH, D.P. (1995). The significance of belief and expectancy within the spiritual healing encounter. Social Science and Medicine, 41, 249-260.

WRIGHT, J.G. (2000). Evaluating the outcome of treatment. Shouldn't we be asking patients if they are better? Journal of Clinical Epidemiology, 53, 549-553.

Zautra, A.J., Okun, A.O.,Robinson, S.E., Lee, D. \& Roth, S.H., Emmanual, J. (1989). Life stress and lymphocyte alternations among patients with rheumatoid arthritis. Health Psychology, 8, 1-14. 